\title{
Karar Örnekleriyle Yargıtay'ın Bilirkişiliğe Bakışı ve Bilirkişiliğin Sorunları
} The Perspective of the Court of Cassation and the Problems Concerning the Expert System in the Light of the Relevant Judgements

\section{Gökhan Karaburun}

Yargitay 11. Ceza Dairesi Üyesi, Ankara

\section{Özet}

Bilirkişi ve bilirkişilik "adil yargılanma hakkı"nı doğrudan etkileyen bir delil değerlendirme aracı olmasına rağmen henüz kurumsallaşmamış olması onu yargının temel problemlerinden biri haline getirmiştir.

6754 sayılı bilirkişilik kanunu ile bilirkişiliğin kurumsallaşması adına önemli bir adım atılmış ise de, bu alana dair temel hukuki denetim aracı kuşkusuz Yüksek Mahkeme kararlarıdır.

Makalede; Yargıtay kararlarındaki ölçütler, 6754 sayılı bilirkişilik kanununda ve ilgili yönetmelikte belirtilen ilkeler ile uygulamada ortaya çıkan çeşitli çözümler göz önüne alınarak bilirkişiliğe Yargıtay'ın bakışı ve buna göre bilirkişinin hukuksal konumu ve sorunları değerlendirmeye çalışılmıştır.

Anahtar Kelimeler: Yargıtay Kararları; Bilirkişi; Rapor; Bilirkişilik Kanunu.

\section{Giriş}

Bilirkişilik kurumu günümüzde yargının en önemli unsurlarından biri olmakla birlikte aynı zamanda en sorunlu alanlarından da birini teşkil etmektedir. Bu sorunların önemli bir kısmı yasal düzenlemelerden değil, uygulamadan kaynaklanmaktadır.

Elbette bilirkişilerin seçimi, yetkinlik düzeyinin belirlenmesi, raporların belli bir standarda sahip olması, görev ve yetki alanındaki açıklık gibi hususlarda bir takım temel ilkeler yüksek yargı organları tarafından verilen kararlara yansıtılmaya çalışılmaktaysa da sorunların çözümü bakımından yeterli olmamaktadır.

Ülkemizde ve genel olarak Kara Avrupa sisteminde (Almanya, Avusturya, Polonya, İsveç, İsviçre ve Belçika'da) "beyanları bağlayıcı olmayan bağımsız bilirkişilik sistemi" uygulanmaktadır. Bu bilirkişiler mahkemeler tarafından atanır, ancak beyanları hakimleri bağla-

Sorumlu Yazar: Gökhan Karaburun Yargitay 11. Ceza Dairesi Üyesi, Ankara

E-mail: g.karaburun@gmail.com

Geliş:18/11/2017 Kabul:30/11/2017

\begin{abstract}
Although the experts and the expert system are tools for assessing the evidence which directly affects "the right to fair trial", it has become one of the major problems of the judiciary system since it has not been institutionalized yet.

Even though the Law No: 6754 on Expert Report has been an important step towards institutionalization of the expert system, the main tool for judicial review in this field is, for sure, the judgments of the high courts.

This article elaborates on the perspective of the Court of Cassation $(\mathrm{CoC})$ regarding the expert system and legal status of the experts considering the criteria used in the judgments of the Court of Cassation, principles described by the Law No: 6754 and relevant regulation and various solutions occurred in practice.

Keywords: Judgments of the Court of Cassation; Expert; Report; Law on Experts.
\end{abstract}

maz. Atama hakimler tarafından yapıldığından, tarafsız olması aranır. Ancak diğer taraftan beyanları takdiri delil olarak nitelendirilir ve hâkimi bağlamamaktadır (1).

Yargitay Ceza Genel Kurulu (E.1998/8-68, K.1998/143) 28.04.1998 tarihindeki bir kararında "bilirkişi, özel ve uzmanlık bilgisini gerektiren konularda sorunun çözümünde uzmanlığından yararlanılan kişi olarak tanımlanmış, uzmanlık gerektirmeyen hâkim veya savcının hukuk bilgisi, kültürü deneyimi ile çözebileceği konularda bilirkişiye başvurmasının CMK'nun 66. maddesine aykırı olduğunu" belirtmiştir.

\section{Yargıtay denetimine konu bilirkişilik ilkeleri}

6754 sayılı Bilirkişilik Kanunu ve Adalet Bakanlığ1 tarafından hazırlanan Bilirkişilik Yönetmeliğinde bilirkişinin özellikleri ile görevlerini ifa sırasındaki ödev ve haklarına ilişkin temel ve etik ilkeler belirlenmiştir. Uygulamaya bakıldığında ise Yargıtay tarafından yerel mahkeme kararları üzerinde en sık denetimi yapılan ve bozma kararlarına esas teşkil eden iki ilke 'yetkinlik' ve 'tarafsızlık'tır. 
Bilirkişinin en önemli özelliklerinin başında alanında uzman ve tarafsız olması gelmektedir. Nitekim Yargıtay'ın çeşitli dairelerince verilmiş kararların analizinde;

- "Konunun ne şekilde uzmanı olduğu anlaşılamayan bilirkişi görüşüne itibarla hüküm tesisi."

- "İhtisas derecesi anlaşılamayan kişinin dayanaksız mütalaasına dayanılarak beraat kararı verilmiş olmas1."

- "Bitkinin hint keneviri olduğunun uzman bilirkişi raporu ile saptanmaması."

- "Dava konusu emvalin fatura ve nakliye tezkeresine uygunluğu hususunda uzman bilirkişi incelemesi yaptırılmadan beraate karar verilmesi."

- "Dava konusu içki, çay ve Çin malı tabakların CIF değerlerinin bu konuda uzman bilirkişi yerine gümrük komisyoncusu olan bilirkişiye tespit ettirilmesi."

- "Kaçak malın değerinin tarafsız bir bilirkişi yerine Gümrük ve Tekel İdaresinde memur olan bir bilirkişiye tespit ettirilmesi."

- "Grafoloji dalında özel uzmanlığı bulanan bir bilirkişiden rapor aldırılması gerekirken adli tıp doktorundan alınan rapora dayanılması."

Gibi sebeplerle birçok kararın bozulmasına karar verildiği görülmekte; bilirkişinin mutlak surette tarafsız, özel bilgi ve uzmanlık sahibi kişi olmasının istendiği anlaşılmaktadır. 6754 sayılı bilirkişilik kanunu ve ilgili yönetmelik hükümlerine göre; Bilirkişilik Daire Başkanlığının görevleri arasında bilirkişilerin sahip olması gereken nitelikleri ve verilecek bilirkişilik temel eğitiminin usul ile esaslarını belirlemek olduğu ayrıca bilirkişilerce hazırlanan raporların özel ve teknik yönü dışında, mevzuata uygunluk bakımından denetiminin de bilirkişilik bölge kurullarınca yapılacağı belirtildiğinden, 6754 sayılı kanun uyarınca bilirkişilerin yetkinliği konusunda ayrı bir denetim mekanizmasının getirilmiş olduğu anlaşılmaktadır.

\section{Bilirkişi incelemesinin hukuki değerlendirmesi ve raporun bağlayıcılığı}

HMK'nın 266-287. maddeleri ve CMK'nın 62-73. maddeleri aralığında bilirkişi incelemesi düzenlenmiştir. $\mathrm{Bu}$ düzenlemelerde bilirkişi incelemesi ve görüşünün hukuki niteliğine ilişkin açıklık ise bulunmamaktadır. $\mathrm{Bu}$ noktada bilirkişi görüşü tanık ifadesi gibi bir delil olarak mı, yoksa bir delil elde etme aracı olarak mı kabul edilecektir?
Doktrinde farklı kabuller bulunmakla birlikte, Yarg1tay 1. Ceza Dairesi 1991 tarihli kararında "Bilirkişi düşüncesi delil değildir. Delil hakkında bir açıklamadır. Bir başka anlatımla delillerin değerlendirilmesi vasıtasıdır. Delil, bilirkişi incelemesi için gerekli olan şeydir. Hâkim bilirkişi incelemesi ile bağlı değildir. Bilirkişinin görevi teknik ve bilimsel anlamda hâkimi aydınlatmaktır." şeklinde görüş ortaya koymuştur.

Nitekim Yargitay Ceza Genel Kurulu' da 24/05/2016 tarihli (2015/12-276 E, 2016/263 sayılı) kararında bilirkişilerin atanmasını, bilirkişi raporları ve bu raporların yargı mercileri nezdinde bağlayıcı olup olmadıklarını irdeleyerek; “... Sahip bulunduğu uzmanlık bilgisiyle mahkemeye bir ispat sorununda yardımcı olup, tanzim ettiği raporu delil değil, "delil değerlendirmesi aracı" olan bilirkişiye başvurmanın amacı, çözümü uzmanlığı, özel veya teknik bilgiyi gerektiren hallerde görüş alınmasıdır. Bununla birlikte ceza muhakemesinde bilirkişi kendiliğinden bir rol edinemez.

Bir sorunun ne zaman uzmanlığ 1 ya da özel veya teknik bir bilgiyi gerektirip gerektirmediğine bilirkişi görevlendirmekle yetkili olan Cumhuriyet savcısı veya hâkim karar verecektir. Anılan hükümler uyarınca hâkim, çözümü ancak özel veya teknik bir bilgi gerektiren hallerde bilirkişi dinleyebilir veya rapor isteyebilir. Hakimlik mesleğinin gerektirdiği genel ve hukuki bilgi ile çözümü mümkün bulunan konularda ise bilirkişiye başvurmayacaktır. Kanun koyucunun uzmanlığa özel veya teknik bir bilgiye ihtiyaç bulunduğunu baştan kabul ettiği "akıl hastalığı, parada sahtecilik, moleküler genetik inceleme" gibi hususlar dışında hâkimin bilirkişi raporu alması mecburiyeti bulunmadığı gibi, bilirkişi raporu da mahkemeyi bağlayıcı nitelikte değildir.

Bilirkişinin kendiliğinden inceleme konusunun sınırlarını aşması veya hukuki sonuç bildirmesi halinde bu husus hâkimi bağlamaz. Çünkü saptanan maddi gerçeğin yasa normundaki ölçütlere göre suç oluşturup oluşturmayacağını tartışıp karar vermek veya somut olayda hukuki vasfin tayinini yapmak hâkimin görevidir.” demektedir.

Aynı konularda;

- (Yargitay 11. Ceza Dairesinin 22.06.2010 tarihli kararı) "Bilirkişinin yetkisi dışında suçun oluşmayacağına ilişkin hukuki sonuç bildiren yetersiz raporuna da dayanılarak eksik soruşturmayla yazılı şekilde hüküm tesisi."

- (Yargitay 11. Ceza Dairesinin 09.02.2010 tarihli kararı) "Bilirkişinin hâkim tarafından değerlendirilmesi gereken ve hukuki görüş içeren suç kastı bulunmadığına dayalı görevini aşan raporuna dayanılmak suretiyle sanığın beraatine karar verilmesi..." hususlarını Yargıtay bozma sebebi yapmıştır. 
$\mathrm{Bu}$ kapsamda uygulama da en çok hata yapılan belgede sahtecilik suçlarındaki bazı özelliklere değinmek gerekirse; bu suçlarda belgenin "iğfal kabiliyeti" yani "aldatıcılık özelliği” bu suçun temel unsuru olup, özel bir incelemeye tabi tutulmadıkça gerçek olmadığı anlaşlamayan belge, sahte belge olarak kabul edilmektedir. Sahteciliğin kişileri aldatacak nitelikte olup olmadığ aldatma unsurunun belgeden objektif olarak anlaşılması gerektiği, muhatabın hatasından, dikkatsizlik ve özensizliğinden kaynaklanan fiili iğfalin, aldatma yeteneğinin varlığını göstermeyeceğini Yargıtay birçok kararında kabul etmiştir.

Yargıtay ayrıca belge incelemesine esas imza karş1laştırmasının, belgenin hazırlanışından sonraki tarihte atılmış imza örnekleriyle yapılmış olmasını bozma sebebi kabul ederek, incelemenin şüphelinin belgeden hem önceki hem de sonraki tarihe ait örneklerle yeniden yapılmasını gerekli görmüştür. Bilimsel olarak bilirkişiye gönderilen mukayese edilecek imza örnekleri ile şüpheli imzanın atılış tarihi arasında beş yıldan fazla süre olmaması gerektiği de kabul edilmiştir (2).

Yargitay 11. Ceza Dairesi kararlarına göre; belge sahteciliği suçlarında bilirkişi, belgenin sahte olup olmadığını teknik yönden inceleyecek, sahte belgenin aldatma kabiliyeti olup olmadığını ise hâkim, suç konusu belge aslını getirtip duruşmada gözlemleyerek yöntemince kendisi değerlendirecektir. Bilirkişi raporunda aldatma kabiliyeti konusunda değerlendirme yapılmış olsa dahi bu görüş hâkimi bağlamayacaktır.

Uygulamada yoğun iş yükünden dolayı hakimlerin kendi hukuksal ve özel bilgileri ile çözebilecekleri konularda dahi bilirkişiye başvurdukları, raporlarında bilirkişileri fiilen hukuki değerlendirme yapmaya zorladıkları görülmekte ise de yukarıdaki kararlarla açıklandığı gibi Yargıtay bu hususu özellikle denetlemektedir.

\section{4. Çelişkili bilirkişi raporları}

Bilirkişi incelemesinin yeterli olup olmadığına karar verecek olan bilirkişi atayan makamdır. Hâkimin, mahkemenin ve Cumhuriyet savcısının bilirkişiye başvurmasının nedeni kendisindeki uzmanlık isteyen bilgi eksikliğinin tamamlanmasıdır. Bu nedenledir ki bilirkişi raporu bu eksikliği gidermiyorsa yeni bir bilirkişi raporu ya da aynı bilirkişiden tereddütleri giderici rapor alınabilir. Peki bu süreçte birbirinden farklı veya birbiriyle çelişen raporların ortaya çıkması halinde hangi rapora hangi nedenle üstünlük tanınacak ve hükme dayanak yapılacaktır?

Yargıtay'ın vermiş olduğu bazı kararlarda yapılacak incelemenin metodunu, hâkimin birinci veya ikinci raporlara göre karar veremeyeceği bu durumda üçüncü kez bilirkişi incelemesi yaptırılması gerektiği bunun yanı sıra birden fazla bilirkişinin görevlendirildiği işlerde azınlıkta kalan bilirkişi raporunu esas alarak hüküm verilemeyeceğini ve çelişkili bilirkişi raporları varsa hangi yöntemle hareket edilmesi gerektiğini uygulamaya yön verecek şekilde açıklamıştır.

Yargitay Ceza Genel Kurulu (2016/9-191,2016/288 K. sayıl1) 31/05/2016 tarihli kararında; "soruşturma aşamasında adli tıp uzmanı tarafından senetteki imzanın sanığa ait olduğu tespit edilmesine rağmen, mahkeme aşamasında Adli Tıp Kurumu Adli belge inceleme şubesindeki üç kişilik inceleme heyetinin imzanın sanığın eli ürünü olup olmadığını tespit edememesi sonucunda, gerçeğin şüpheye yer vermeyecek şekilde tespiti bakımından suça konu senetlerin sanığın eli ürünü olup olmadığı konusunda Adli Tıp Kurumu Fizik İhtisas Dairesinde yöntemince grafolojik inceleme yapılması ve raporlar konusunda kuşkunun giderilmesi gerektiğini” hükme bağlamıştır.

Yargitay 11. Ceza Dairesi (2015/7039 Esas, 2017/7196 K. sayıl1) 26.10.2017 tarihli kararında; “... Jandarma Kriminal raporunda senet üzerindeki şikayetçiye ait imzanın onun eli ürünü olmadığının ve onun imzası taklit edilmek suretiyle atıldığının belirtildiği, Adli Tıp fizik İhtisas Dairesi'nin raporu ile de senetteki şikayetçiye atfen atılı borçlu imzalarının şikayetçiye ait olduğunun rapor edildiği anlaşıldığından; raporlar arasında çelişki olması nedeniyle bu çelişkinin giderilmesi bakımından üniversitede görevli uzman kişilerden oluşacak bilirkişi kurulundan veya Adli Tıp Kurumu genişletilmiş ihtisas dairesinden rapor alınması ya da mevcut raporlardan hangisine üstünlük tanındığının tartışılarak nedenlerinin gerekçeli kararda gösterilmesi gerektiği gözetilmeden eksik araştırma ve yetersiz gerekçe ile hükümler kurulması" nedenleriyle kararı bozarak çelişkili bilirkişi raporlarında mahkemenin hangi yöntemle hareket etmesi gerektiğini belirtmiştir.

Yargitay 12. Hukuk Dairesi ise 22.02.2004 tarihli (E.2004/5818, K.2004/10153) kararında "bilirkişi raporunda hangi ortamda ne tür teknik cihazlar kullanılarak inceleme yapılıp sonuca varıldığının açıklanmadığını, sadece grafolojik ve grafometrik metotların uyguland1ğının belirtildiği, ulaşılan sonucun maddi dayanaklarının denetime elverişli şekilde ortaya konmadığını, bu itibarla bilirkişi raporuna dayanılarak hüküm kurulamayacağını," belirterek kararı bozmuştur.

Bu kararlarda üzerinde önemle durulan husus; bilirkişi olarak tayin edilecek kişi veya kurumun inceleme konusu üzerindeki uzmanlığ 1 ve hakimiyeti olduğu kadar, bilirkişiyi görevlendiren merciinin çelişkili raporlar arasında olayın oluşuna en uygun olan hangi rapora üstünlük tanıdığını gerekçeli kararında tartışmasıdır.

Birçok Yargıtay kararında bilirkişi raporları arasında- 
ki çelişkinin giderilmesi için Adli Tıp Kurumuna başvurulması gerektiği işaret edilmekteyse de bu husus sadece yerel mahkemeye yön göstermek amaçlı olup, 2659 sayılı Adli Tıp Kurumu Kanununun 23/C-3 maddesi de dikkate alındığında Adli Tıp Kurumunun resmi bilirkişi sıfatı bulunmasının onu son merci yapmayacağ 1 ve kurum tarafından verilen raporlara sırf bu nedenle üstünlük tanınmayacağı açıktır.

Yargitay 12. Hukuk Dairesi 20.03.2007 tarihli (2007/2366-5280 esas ve karar sayılı) kararında "Adli Tıp Kurumu grafoloji (bugün adli belge inceleme şubesi olarak ismi değiştirilen bölüm kastedilmektedir) bölümünün imza incelemesinde son merci olarak kabulünün mümkün bulunmadığını" belirtmiş, yine aynı daire 26.11.2012 tarihli (2012/17547E, 34790K) kararında "Adli Tıp Kurumu Fizik İhtisas Dairesinin imza incelemesinde son merci olarak kabulü mümkün bulunmayıp, raporun anılan kurumdan alınmış ve heyetçe düzenlenmiş olması da yerleşik Yargıtay içtihatlarına göre ona üstünlük tanımayacağından anılan rapora itibar edilerek sonuca gidilemez." demek suretiyle bu hususu vurgulamıştır.

\section{Bilirkişi incelemesindeki yöntem ve esaslar}

Bilirkişilerin genel olarak hangi yöntemlerle çalışmalarını sürdürüp rapor vereceklerine dair yöntem ve esasları gösteren bir Yargıtay kararı yok ise de; Amerika Birleşik Devletlerinde federal mahkemeler, Yüksek mahkeme tarafindan 1993 yılında belirlenen ve Bilirkişilikte "Daubert Standartları" olarak bilinen kuralları baz almaktadır. “Daubert Standartları”na göre, hakimler bilirkişi sorgulamasının bilimsel geçerliliğinin metodolojik ve mantıksal temelleri bulunup bulunmadığını ve metodolojik temellerin yargılama konusunu oluşturan uyuşmazlığa uygulanmasının mümkün olup olmadığına dair bir ön inceleme yapacaklardır. Bu ön inceleme, bilirkişi görüşlerinin bir teste tabi tutulması anlamına gelmektedir. Buna göre bilirkişi açıklamalarının;

I. Sınırları belirlenmiş ve bunun test edilebilir olması gerekir.

II. İncelemeye ve değerlendirmeye tabi tutulabilir olması gerekir.

III. Alınan bilginin hata oranı, istatistiksel olarak belirlenebilir olmalıdır.

IV. İlgili bilim çevresinde kabul görmüş olmalıdır (3).

Yargıtay'ın ise daha özel bir alanda, adli belge incelemesinde uygulanacak yöntem ve esaslar ile ilgili Genel Kurul kararları mevcuttur. Şöyle ki; Ceza Genel Kurulu (2006/9-191E, 288K sayıl1) 31.05.2016 tarihli kararın- da; "Belgede sahtecilik suçlarında sahtecilik olgusunun saptanması özel ve teknik bilgiyi gerektirdiğinden, bu tür bir incelemenin öncelikle bünyelerinde grafoloji uzmanı bulunduran resmî kurumlara, bu mümkün olmadığı takdirde ise incelemenin grafoloji uzmanlarına yaptırılması zorunludur." demek suretiyle belge incelemelerinde sadece uzmanlığa vurgu yapmaktadır.

Hukuk Genel Kurulu ise 30/05/2001 tarihli (2001/12246 E ve 2001/467 say1li) kararında; "Herhangi bir belgedeki imza veya yazının, atfedildiği kişiye ait olup olmadığı hususunda yapılacak bilirkişi incelemesinin, konunun uzmanın ve yeterli teknik donanıma sahip bir laboratuvar ortamında, optik aletler ve o incelemenin gerektirdiği diğer cihazlar kullanılarak; grafolojik ve grafometrik yöntemlerle yapılması; bu alet ve yöntemlerle gerek incelemeye konu ve gerekse karşılaştırmaya esas belgelerdeki imza veya yazının tersi, seyir, baskı derecesi, eğim, doğrultu gibi yönlerden taşıdığı özelliklerin tam ve kuşkuya yer vermeyecek şekilde belirlenip karşılaştıılması; sonuçta imza veya yazının atfedilen kişiye ait olup olmadığının, dayanakları gösterilmiş, tarafların, mahkemenin ve Yargıtay'ın denetime elverişli bir raporla ortaya konulması; gerektiğinde karşılaştırılan imza veya yazının hangi nedenle farklı veya aynı kişinin eli ürünü olduklarının fotoğraf ya da diğer uygun görüntü teknikleri ile de desteklenmesi şarttır" demektedir.

Buna göre; tüm hukuk davalarında adli belge incelemeleri için görev verilen uzman bilirkişilerin öncelikle yeterli teknik donanıma sahip bir laboratuvar ortamında raporlarını hazırlamaları zorunlu iken ceza davalarında adli belge incelemeleri için gerekmedikçe böyle bir zorunluluğun olmadığı anlaşılmaktadır.

Hukuk Genel Kurulunun kararında bahsettiği "yeterli teknik donanıma sahip bir laboratuvarın" nasıl olacağına dair bir yasal düzenleme veya bir karar henüz bulunmamaktadır. Yine yazı ve imza incelemelerinde elde edilen bulguların değerlendirilmesinde bir veri tabanı oluşturulmadığından, tespit edilen bulguların kanıt değeri istatistiksel olarak da araştırılamamaktadır. Tüm bunlar, kanaatimizce verilen raporların bilimsel olarak değerlendirilmesinde önemli eksikliklerdir.

\section{a) Bilirkişilerin duruşma sırasında dinlenilmesi}

Bilirkişi raporlarının değerlendirilmesi, irdelenmesi ve denetlenmesi bakımından; HMK'nın 152 ve 281/2. maddeleriyle, CMK'nın 68, 71 ve 201. maddelerinde düzenlenen 'bilirkişinin duruşma sırasında dinlenmesi' ve 'doğrudan soru yöneltme' şeklindeki muhakeme araçlarına da değinmek faydalı olacaktır. Zira sadece hazırlanan raporun sunulması bilirkişilik görevinin tamam- 
lanması için yeterli değildir. Mahkeme her zaman bilirkişinin duruşmada dinlenmesine ve ilgililerin istemesi halinde açılamada bulunmak üzere duruşmaya çağrılmasına karar verebilir.

Bilirkişi duruşmaya davet edilmesi durumunda ise bir muhakeme arac1 olan doğrudan soru yöneltme ile muhatap olacaktır. HMK'nın 152 ve CMK'nın 68 ve 201. maddelerine göre bilirkişilere karşı hukuk davasında taraf vekillerinin, ceza davasında ise Cumhuriyet savcıs1nın, vekilin ve müdafinin doğrudan soru yöneltme hakkı düzenlenmiştir. Öngörülebileceği üzere bilirkişinin niteliği, konuşma hakimiyeti ve alanındaki başarıları raporun kuvvetini arttıran etkilerdir. Özellikle aynı konuya ilişkin farklı bilirkişilerden rapor veya görüş alındığı durumlarda görüşler arasında farklılıkların bulunması halinde niteliğin önemi daha da ön plana çıkmaktadır. Bu kapsamda duruşma sırasında dinleme ve doğrudan soru yöneltme araçları ile; bilirkişinin vasıfları, dereceleri, eğitimi, konumu, profesyonel meslek gruplarına üyelikleri, bilirkişilik yaptığı alandaki uzmanlığı ve bunları nasıl elde ettiği gibi hususlar bilirkişiye bizzat onaylattırılarak ortaya konacak, kesin ve doğrudan sorular ile varsa rapordaki teknik husus veya kullanılan dilin açıklattırılması sağlanmış olacaktır.

İyi bir uzman da mahkeme salonunda tarafsız olmak, zorluklara dikkat çekmek ve konunun yabancısı olanlara anlaşılır bir dil ile düşüncelerini aktararak mahkemeyi konusu ile ilgili aydınlatmak durumundadır. CMK'nın 66/6. maddesi uyarınca ve gerekli olması halinde bilirkişi de mağdur, şüpheli veya sanığa mahkeme başkanı veya hâkim (soruşturma evresinde Cumhuriyet savcısı) aracılığı ile soru sorabilir. Mahkeme başkanı veya hâkim (soruşturma evresinde Cumhuriyet savcısı), bilirkişinin doğrudan soru sormasına da izin verebilir.

\section{b) Bilirkişinin rapor süresi}

Bilirkişinin uygulamadaki en önemli ödevine yani rapor verme ve duruşma sırasında görüş bildirme yükümlüğüne değinmişken, uygulamada bu hususta karşılaşılan başka bir sorun olan rapor süresi konusuna da dikkat çekmek faydalı olacaktır. Bilindiği üzere, HMK'nın 274/1 ve CMK'nın 66. maddelerinde bilirkişiye görevini yerine getirmek için verilecek uygun sürenin özel ve haklı sebepler olmadıkça üç ayı geçemeyeceği düzenlenmiştir. Anılan süre içinde haklı mazereti olmaksızın raporunu vermeyen bilirkişiyi hâkim görevden alır ve tazminat ile ceza sorumluluğu saklı kalmak üzere kendisine ödeme yapılmamasına karar vererek, 6754 sayılı kanuna göre gerekli yaptırımların uygulanmasını bilirkişilik bölge kurulundan ister.

Konuya ilişkin Avrupa İnsan Hakları Mahkemesinin
21.12.2006 tarihli Oruç /Türkiye (33620/02) kararında; "Dava konusu olayda mahkemenin sahte olduğu iddia edilen evrakın yorumlanması için dava dosyasını bilirkişiye göndermiş olması ve takip eden yedi (7) duruşma boyunca bilirkişiden cevap alınamaması ve duruşmanın yeniden ertelenmesi nedeniyle başvurucunun yargılama süresinin AİHS m. 6/1 de düzenlenen makul sürede yargılanma hakkının ihlal edildiğine dair" karar vererek başvurucunun talebini yerinde görmüş ve Türkiye'yi AİHS'in 6/1 maddesini ihlal etmekten sorumlu bulmuştur. Kararda da belirtildiği üzere bilirkişinin makul sürede görüşünü mahkemeye rapor olarak sunması ve davet edilmesi halinde duruşmada konuya ilişkin detaylı bilgi sunmas1, Anayasamızın 36. maddesinde düzenlenen ve yargılamanın makul sürede bitirilmesini de kapsayan adil yargılanma hakkı bakımından oldukça önemlidir.

\section{Bilirkişinin hukuksal konumu ve ceza hukuku yönünden sorumlulukları}

5237 sayılı TCK'nın 6. maddesinde, ceza kanunlar1nın uygulanması yönünden kamu görevlisi "kamusal faaliyetin yürütülmesine atama veya seçilme yoluyla ya da herhangi bir surette sürekli, süreli veya geçici olarak kat1lan kişi” olarak tanımlanmıştır. Bu maddenin gerekçesinde ise, bilirkişilik, tercümanlık ve tanıklık yapan kişinin, bu faaliyetlerinin icrası kapsamında kamu görevlisi olduğu belirtilmiştir. Yine, 6100 sayılı HMK'nın 284. maddesinde ve bilirkişilik yönetmeliğinin 58. maddesinde bu husus ayrıca düzenlenerek "Bilirkişi Türk Ceza Kanunu anlamında kamu görevlisidir" hükmü konulmuştur.

$\mathrm{Bu}$ düzenlemelere göre bilirkişi, bilirkişilik görevi kapsamında "kamu görevlisi” sayılmaktadır. Tanıklara ilişkin hükümler, kural olarak, bilirkişiler hakkında da uygulanır (CMK m 62) (Maddî gerçeğin ortaya çıkmasına yardım ettikleri için bilirkişi ile tanık arasında benzerlik olmakla birlikte önemli farklar da vardır; tanığın yeri doldurulamaz, ancak bilirkişinin yerine bir başkası bilirkişi olarak atanabilir. Bilirkişi, önceden bilmediği ve görmediği konu ile ilgili bir olgu veya belge hakkında görüş bildirmektedir. Tanık ise, gördüğü, bildiği veya duyduğu bir şeyi yetkili merci huzurunda açıklamaktadır.) Bilirkişinin disiplin (bilirkişilik yönetmeliği md. 60-64) ve tazminat sorumluluğu (HMK md. 285-287) dişında ceza sorumluluğuna kısaca bir değinmek gerekirse; Bilirkişinin görevini yaparken veya bu göreviyle bağlantılı olarak işleyebileceği suçların tamamı, kasit varsa oluşabilecek suçlardır. Bu suçların bilirkişilik göreviyle bağlantılı olarak işlenmesi halinde "adli görev" kapsamında kalacağından Cumhuriyet savcısı tarafindan genel hükümlere göre soruşturma yapılacaktır. Şüphesiz ki bilirkişiye yönelik görevi dolayısıyla işlenen suçlarda da, bu suçun faili kamu 
görevlisine karşı suç işlemiş gibi cezalandırılacaktır.

Bilirkişilerin Türk Ceza Kanunu kapsamında karşılaşabilecekleri soruşturma maddeleri şunlardır;

\section{a) Gerçeğe Aykırı Bilirkişilik Yapma}

Gerçeğe aykırı bilirkișilik veya tercümanlık Madde 276- (1) Yargı mercileri veya suçtan dolayı kanunen soruşturma yapmak veya yemin altında tanık dinlemek yetkisine sahip bulunan kişi veya kurul tarafindan görevlendirilen bilirkişinin gerçeğe aykırı mütalaada bulunması halinde, üç yıldan yedi yıla kadar hapis cezasına hükmolunur.

Yargitay 4. Ceza Dairesi 19.07.2007 tarihli kararında "bilirkişilerin icra müdürlüğünce kıymet takdiri yapılmak üzere görevlendirdikleri konutu görmeden değer tespiti yaparak rapor düzenlemelerini TCK 276. maddesine uyan "gerçeğe aykırı bilirkişilik" suçunu oluşturacağını" belirtmiştir.

Yargitay 21. Ceza Dairesi ise 07.03.2016 tarihli kararı ile “... mahalli bilirkişilik yapan sanıkların kadastro tutanaklarının düzenlendiği sırada gerçeğe aykırı bilirkişilik yapmak suretiyle köye ait meraları kendileri ve akrabalarının üzerine geçirilmesini sağladıklarının iddia olunması karşısında eylemin TCK'nın 276. maddesinde öngörülen "gerçeğe aykırı bilirkişilik suçunu oluşturacağı." yönünde hüküm kurmuştur. Benzer pek çok karar bulunmaktadır.

\section{b) Bilirkişinin Görevini Yapmakta İhmal Veya Gecikme Göstermesi}

Görevi kötüye kullanma Madde 257- (2) Kanunda ayrıca suç olarak tanımlanan haller dışında, görevinin gereklerini yapmakta ihmal veya gecikme göstererek, kişilerin mağduriyetine veya kamunun zararına neden olan ya da kişilere haksız bir kazanç sağlayan kamu görevlisi, üç aydan bir yıla kadar hapis cezası ile cezalandirılır.

Yargitay 2. Ceza dairesi 30.06.2008 tarihli kararında "Bilirkişilik görevinin ihmal suçunun oluşması için bilirkişinin davet olunup da asılsız bir sebep ileri sürerek gelmemesi veya gelip de asılsız bir sebep ileri sürmek suretiyle bilirkişilik etmekten imtina etmiş olması gerekir.” diyerek bu suçun hangi halde oluşabileceğini göstermiştir.

\section{c) Bilirkişilik Görevini Kötüye Kullanma}

Görevi kötüye kullanma Madde 257. (1) Kanunda ayrıca suç olarak tanımlanan haller dışında, görevinin gereklerine aykırı hareket etmek suretiyle, kişilerin mağduriyetine veya kamunun zararına neden olan ya da kişilere haksız bir kazanç sağlayan kamu görevlisi, altı aydan iki yıla kadar hapis cezası ile cezalandırılır.

\section{d) Bilirkişinin Göreve İlişkin Sırrı Açıklaması}

Göreve ilişkin sırrın açıklanması Madde 258. - (1) Görevi nedeniyle kendisine verilen veya aynı nedenle bilgi edindiği ve gizli kalması gereken belgeleri, kararları ve emirleri ve diğer tebligatı açılayan veya yayınlayan veya ne suretle olursa olsun başkalarının bilgi edinmesini kolaylaştıran kamu görevlisine, bir yıldan dört yıla kadar hapis cezası verilir.

(2) Kamu görevlisi sıfatı sona erdikten sonra, birinci fıkrada yazılı fiilleri işleyen kimseye de aynı ceza verilir.

\section{e) Bilirkişinin İşlendiğini Öğrendiği Suçu Bildirmemesi}

Kamu görevlisinin suçu bildirmemesi Madde 279. (1) Kamu adına soruşturma ve kovuşturmayı gerektiren bir suçun işlendiğini göreviyle bağlantılı olarak öğrenip de yetkili makamlara bildirimde bulunmayı ihmal eden veya bu hususta gecikme gösteren kamu görevlisi, altı aydan iki yıla kadar hapis cezası ile cezalandırılır.

\section{f) Suç Delillerini Yok Etme, Gizleme Veya Değiştirme}

Madde 281. - (1) Gerçeğin meydana çıkmasını engellemek amaciyla, bir suçun delillerini yok eden, silen, gizleyen, değiştiren veya bozan kişi, altı aydan beş yıla kadar hapis cezası ile cezalandırılır. Kendi işlediği veya işlenişine iştirak ettiği suçla ilgili olarak kişiye bu fikra hükmüne göre ceza verilmez. Bu suçun kamu görevlisi tarafından göreviyle bağlantılı olarak işlenmesi halinde, verilecek ceza yarı oranında artırılır. İlişkin olduğu suç nedeniyle hüküm verilmeden önce gizlenen delilleri mahkemeye teslim eden kişi hakkında bu maddede tanımlanan suç nedeniyle verilecek cezanın beşte dördü indirilir.

\section{g) İrtikap}

Madde 250. - (1) Görevinin sağladığı nüfuzu kötüye kullanmak suretiyle kendisine veya başkasına yarar sağlanmasına veya bu yolda vaatte bulunulmasina bir kimseyi icbar eden kamu görevlisi, beş yıldan on y1la kadar hapis cezası ile cezalandırılır. Görevinin sağladığı güveni kötüye kullanmak suretiyle gerçekleştirdiği hileli davranışlarla, kendisine veya başkasına yarar sağlanmasina veya bu yolda vaatte bulunulmasina bir kimseyi ikna eden kamu görevlisi, üç yıldan beş yıla kadar hapis cezası ile cezalandırılır. İkinci fikrada tanımlanan suçun kişinin hatasından yararlanarak işlenmiş olması halinde, bir yıldan üç yıla kadar hapis cezasına hükmolunur.

Yargitay 5. Ceza Dairesi 16.07.2009 tarihli kararında "bilirkişinin davacıdan para talep ederek istenilen şekil- 
de rapor yazabileceğini, para vermezse yasal durum neyi gerektiriyorsa o şekilde rapor yazacağını söyleyerek para almasının irtikap değil, basit rüşvet alma suçunu oluşturacağını" belirtmiştir. Yargıtay 5. Ceza Dairesinin benzer nitelikte pek çok kararı bulunmaktadır.

\section{h) Rüşvet Alma}

Madde 252. - (Değişik madde: 02/07/2012-6352 S.K./87.md.)

1. Görevinin ifasıyla ilgili bir işi yapması veya yapmaması için, doğrudan veya aracılar vasıtasıyla, bir kamu görevlisine veya göstereceği bir başka kişiye menfaat sağlayan kişi, dört yıldan oniki yıla kadar hapis cezası ile cezalandırılır.

2. Görevinin ifasıyla ilgili bir işi yapması veya yapmaması için, doğrudan veya aracılar vasıtasıyla, kendisine veya göstereceği bir başka kişiye menfaat sağlayan kamu görevlisi de birinci fikrada belirtilen ceza ile cezalandırılır.

3. Rüşvet alan veya talebinde bulunan ya da bu konuda anlaşmaya varan kişinin; yargı görevi yapan, hakem, bilirkişi, noter veya yeminli mali müşavir olması halinde, verilecek ceza üçte birden yarısına kadar artırılır.

Bilirkişi Ücreti: CMK'nın 72. maddesinde "Bilirkişiye, inceleme ve seyahat gideri ile çalışmasıyla orantılı bir ücret ödenir", HMK 283. maddesinde ise "Bilirkişiye, sarf etmiş olduğu emek ve mesaiyle orantılı bir ücret ile inceleme, ulaşım, konaklama ve diğer giderleri ödenir. $\mathrm{Bu}$ konuda, Adalet Bakanlığınca çıkarılacak ve her yıl güncellenecek olan tarife esas alınır." hükümleri yer almaktadır. Ayrıca 6754 sayılı kanun ve ilgili yönetmelikle Bilirkişilik Daire Başkanlığına "Bilirkişilik Asgari Ücret Tarifesini belirlemek ve her yıl güncellemek" görevi verilmiştir. Konusunda uzman olan bir kişinin, adliyeye gidip dosyayı alması, zaman ayırı inceleme yapması, keşfe katılması, rapor hazırlaması ve tekrar mahkemeye sunması gibi işlemleri özellikle metropol boyutundaki kentlerde bilirkişinin yerine getirmesi, son derece zor ve fedakârlık gerektiren bir eylemdir. Ayrıca bu tutar içinden vergi de kesilmektedir. Burada, bilirkişinin genellikle bir fikir ürünü olarak ortaya konan emeğinin değerlendirilmesi oldukça önem taşır. Bütün bunlar dikkate alındığında bilirkişiyi görevlendiren merci, bilirkişilik kurumunun, verimli ve başarılı olarak işletilmesini sağlamak için bilirkişinin eğitim ile deneyiminin sonucu olarak kazandığı uzmanlık bilgisinin değerine, yapılan işe, verilen emeğe uygun, orantılı ve adil bir ücreti yeni bilirkişilik kanunu ile daire başkanlığınca düzenlenecek asgari tarifenin altında olmayan bir miktarda takdir et- mek durumundadır.

\section{Bilirkişinin görev sınırları ve ödevleri}

$\mathrm{Bu}$ kapsamda HMK ve CMK' daki düzenlemeler, 6754 sayılı Bilirkişilik Kanununda ve Bilirkişilik Yönetmeliğinde belirlenen temel ilkeler ile uygulama dikkate alındığında rapor düzenlemesi sırasında bilirkişiye yüklenen ödevleri ve görev sınırlarını genel olarak şu şekilde değerlendirebiliriz;

- Bilirkişinin, hukuksal konularda bilgi verme ve hukuksal değerlendirme yapma yetkisi yoktur. Kendisinden hukuksal konuda görüş istendiğinde, bilirkişilik görevini geri çevirmelidir.

- Verilen görevin kapsamı açıklanmamış ise; bilirkişi, kendisini atayan merciden, istemin ve verilen görevin sınırlarının açık ve kesin biçimde belirlenmesini istemelidir (4). Uygulamada bilirkişilere dosya tevdi edilirken onlardan talep edilen hususların net bir şekilde belirtilmeyip görev kapsamının muğlak bırakıldığı görülmektedir.

- Kendisinden olgu belirlenmesi istenmiş ise; bilirkişi, olgunun belirlenmesinde kullanılan yöntemler ile özel ve teknik kuralların neler olduğunu açıklayarak olguyu belirlemelidir. Örneğin ticari defterlerin yöntemine göre tutulup tutulmadığını saptarken; ilgili kural ve ilkelerin neler olduğunu açıklamalıdır. *(Aşçığlu, agb, s.87)

- Kendisinden olay değerlendirmesi istenmiş ise; bilirkişi, çalışmasında belirlediği olguları ve bunları hangi teknik ve bilimsel yöntemlere ve kurallara göre belirlediğini açıklayarak değerlendirme yapmalıdır. *(Aşçığlu, agb, s.87)

- Bilirkişinin yetkisi, kural olarak kendisine verilen görevle sınırlıdır. Hukuk davalarında HMK'nın $25-26$ ve 273. maddelerindeki ilkeler bilirkişiyi de bağlar ve inceleme yapılacak konunun kapsam ve sınırları dışına çıkamaz. Ancak;

- İnceleme sırasında, konunun olağan kapsamı ve uzantısı içinde bulunan bir durum ortaya çıktığında, bunu da inceleyip raporunda açıklamalıdır.

- Ceza davalarında suçla ilgili olan başka bir durumu saptadığında örneğin, çekte imza incelemesi yaparken, keşide tarihinde tahrifat yapıldığını görüp belirlediğinde, bunu da inceleyip raporunda belirtmelidir.

- Bilirkişi mesleki ve teknik bilgisini somut olaya uygulayıp bundan çıkacak bilimsel ve maddi sonuçları saptamakla yükümlüdür. Kendisine görev olarak verilen konunun çözümüne ilişkin birden çok olasılık varsa; bilirkişi, her seçeneği ayrı ayrı 
inceleyip gerekçesi ve dayanakları ile birlikte kullandığ 1 teknik terim ve ifadelerini raporunu sunduğu merci ve taraflarında anlayabileceği bir sadelikte raporunda açıklamalıdır. Bilirkişi yalnızca yanıtını bildiği soruları cevaplamalı, kendi alanı ve bilgisiyle açıklayamayacağ 1 konularda yorum yapmamalıdır. Kendi alanında tartışmalı olan konularda ise konuyu tüm boyutlariyla ele aldıktan sonra kendi görüşünü rapora yazmalıdır. Dolayısıyla bilirkişinin raporları bilime, kendi meslek disiplini ile dosya kapsamına uygun olmalıdır ve Yargitay bu hususu denetlemektedir.

\section{Sonuç}

Bilirkişilik müessesesi günümüzde yargının en önemli unsurlarından biri olmakla birlikte aynı zamanda en sorunlu alanlarından da birini teşkil etmektedir. Bilirkişiliğe ilişkin uygulamada pek çok sorun vardır. Başlıcaları olarak sayabileceklerimiz; bilirkişilere dosya dağıtımındaki adaletsizlik, Uyap sisteminden tam olarak yararlanamama, bilirkişi ücretlerinden kesilen vergi, ceza davalarında bilirkişilerin büyük miktarlardaki alacaklarının zamanında ödenmemesi, inceleme için toplanan materyalin yetersizliği ile nitelikli bilirkişi azlığı gibi birçok sorunu siralayabiliriz.

Temel sorun ise bilirkişiliğin kurumsallaşmamış olmasıdır. Bu noktada Adalet Bakanlığı ile Avrupa Birliği arasında 2013-2015 yılları arasında yürütülen "Geliştirilmiş Bilirkişilik Sistemi Eşleştirme Projesi” kapsamında yaşanan sorunların çözümü için bilirkişilerin sertifikasyonu, eğitimi, denetimi ve performans ölçümlerinin ya- pılması, bilirkişilere yönelik düzenleyici ve denetleyici bir yapının kurulması ihtiyacı vurgulanmış ve sorunların çözümü için önemli bir başlangıç olarak kabul edilebilecek 6754 sayılı Bilirkişilik Kanununda kurumsallaşmaya yönelik düzenlemeler yapılmıştır.

$\mathrm{Bu}$ yasa bilirkişiliğin kurumsallaşması için önemli bir başlangıç sayılsa da, yasanın 2/b maddesinde bilirkişi olarak sayılan özel hukuk tüzel kişilerinin uluslararası akreditasyon şartına bağlanmamasının, Adli Tıp Kurumunun Adli Bilimler Kurumu olarak yapılandırılıp daha özerk bir yapıya dönüştürülmemesinin ve yasa ile oluşturulan bilirkişilik danışma kurulu ile daire başkanlığının bağımsız bir yapı içinde olmamasının yasada düzeltilmesi gerekli hususlar olarak değerlendirmekteyim. Kanaatimce yargısal alana özgü bir işlev üstlenen bilirkişilik bu açıdan daha az yürütme ile daha çok yargı ile ilişkilendirilerek tesis edilmelidir. Bilirkişi ve bilirkişilik kurumuna duyulacak güven artışı "adil yargılanma hakkı"nın tesisi bakımından aynı ölçüde yargıya olan güveni de arttıracaktır.

\section{Kaynaklar}

1. Demirkapı E. Anglo-Amerikan hukukunda bilirkişilik kurumunda yeni eğilimler

2. Sayıcı B. Türkiye'de hukuk ve adli bilimler açısından imza ve karşılaşılan sorunlar, Yüksek Lisans Tezi

3. Demirkapı E. Anglo-Amerikan Hukukunda Bilirkişilik Kurumunda Yeni Eğilimler. Dokuz Eylül Üniversitesi Hukuk Fakültesi Dergisi. 2003;5(2):39-75

4. Aşçığlu Ç. Bilirkişilik Kavramı ve Görev Sınırları, Bildiri, Barolar Birliği Bilirkişilik Sempozyumu 2001 